\title{
CD38-CADPR-SERCA Signaling Axis Determines Skeletal Muscle Contractile Force in Response to $\beta$-Adrenergic Stimulation
}

\author{
Dae-Ryoung Parka,b Tae-Sik Nam ${ }^{a, b}$ Ye-Won Kim ${ }^{a, b} \quad$ Seo-Ho Lee Le,b $^{a, b}$ \\ Uh-Hyun Kimª,c
}

aDepartment of Biochemistry ${ }^{b}$ National Creative Research Laboratory for $\mathrm{Ca}^{2+}$ signaling Network, 'Institute of Cardiovascular Research, Chonbuk National University Medical School, Jeonju, Korea

\section{Key Words}

$\beta$-adrenergic receptor signal $\cdot \mathrm{CD} 38 \cdot \mathrm{CADPR} \cdot \mathrm{SERCA} \cdot$ Skeletal muscle contraction

\begin{abstract}
Background/Aims: Cyclic ADP-ribose (CADPR) is a $\mathrm{Ca}^{2+}$-mobilization messenger that acts on ryanodine-sensitive $\mathrm{Ca}^{2+}$ channels in the sarcoplasmic reticulum (SR) $\mathrm{Ca}^{2+}$ stores. Moreover, it has been proposed that CADPR serves an additional role in activating the sarcoendoplasmic reticulum $\mathrm{Ca}^{2+}$-ATPase (SERCA) pump. The aim of this study was to determine the exact mechanism by which CADPR regulates $\mathrm{SR} \mathrm{Ca}^{2+}$ stores in physiologically relevant systems. Methods: We analyzed $\mathrm{Ca}^{2+}$ signals as well as the production of $\mathrm{Ca}^{2+}$ mobilizing messengers in the skeletal muscle cells of mice subjected to intensive exercise or in the SR fractions from skeletal muscle cells after $\beta$-adrenergic receptor ( $\beta$-AR) stimulation. Results: We show that CADPR enhances SERCA activity in skeletal muscle cells in response to $\beta$-AR agonists, increasing $\mathrm{SR} \mathrm{Ca}{ }^{2+}$ uptake. We demonstrate that CADPR is generated by CD38, a CADPR-synthesizing enzyme, increasing muscle $\mathrm{Ca}^{2+}$ signals and contractile force during exercise. CD38 is upregulated by the CAMP response element-binding protein (CREB) transcription factor upon $\beta$-AR stimuli and exercise. CD38 knockout (KO) mice show defects in their exercise and CADPR synthesis capabilities, lacking a $\beta$-AR agonist-induced muscle contraction when compared to wild-type mice. The skeletal muscle of CD38 KO mice exhibits delayed cytosolic $\mathrm{Ca}^{2+}$ clearance and reduced SERCA activity upon exercise. Conclusion: These findings provide insight into the physiological adaptive mechanism by which the CD38- CADPR-SERCA signaling axis plays an essential role in muscle contraction under exercise, and define CADPR as an endogenous activator of SERCA in enhancing the SR $\mathrm{Ca}^{2+}$ load.
\end{abstract}

D.R. Park and T.S. Nam contributed equally to this work 


\section{Introduction}

Ever since it was first described as the trigger of muscle contraction seven decades ago, $\mathrm{Ca}^{2+}$ has been recognized as a universal signal in muscle cells as well as nonmuscle cells [1]. Muscle contraction (inotropy) requires appropriate $\mathrm{Ca}^{2+}$ release from the sarcoplasmic reticulum (SR) into the cytosol, while muscle relaxation (lusitropy) relies on $\mathrm{Ca}^{2+}$ uptake from the cytosol into the SR via the sarcoendoplasmic reticulum $\mathrm{Ca}^{2+}$-ATPase (SERCA) pump $[2,3]$. Physiological sympathetic stimulation of the skeletal muscle through $\beta$-adrenergic receptors ( $\beta$-ARs) enhances contractions and accelerates relaxation. The stimulation of $\beta$-AR activates a GTP-binding protein $\left(\mathrm{G}_{\mathrm{s}}\right)$, which stimulates adenylyl cyclase to produce cAMP, which in turn activates protein kinase A. This kinase phosphorylates several signaling proteins related to muscle contraction and relaxation. During physical exercise, as a fight-or-flight response, plasma $\beta$-AR stimulating hormone (catecholamines) concentrations are increased [4]. The activation of $\beta$-AR by agonists is known to increase force generation through the regulation of intracellular $\mathrm{Ca}^{2+}$ concentrations in skeletal muscle $[5,6]$. However, the mechanism by which $\mathrm{Ca}^{2+}$ handling contributes to an increase in the contractile force of skeletal muscle under sympathetic control has not been elucidated.

Accumulating evidence suggests that cyclic ADP-ribose (cADPR) and nicotinic acid adenine dinucleotide phosphate (NAADP) play an essential role in $\mathrm{Ca}^{2+}$ mobilization from $\mathrm{Ca}^{2+}$ stores in a variety of cell types, including skeletal muscle cells [7-9]. We and others have found that both NAADP and CADPR are generated in the heart in response to $\beta$-AR agonists, resulting in physiological or pathological changes, which indicates that $\mathrm{Ca}^{2+}$ second messenger formation under $\beta$-AR stimulation has a pivotal role in regulating intracellular $\mathrm{Ca}^{2+}$ levels $[10,11]$. CD38 has been well characterized as a mammalian prototype of ADP-ribosyl cyclase (ARC), which can produce two $\mathrm{Ca}^{2+}$ mobilizing messengers: cADPR and NAADP [12, 13]. However, there also exist as-yet-unidentified non-CD38 ARCs and NAADP-synthesizing enzymes in mammalian tissues, including the skeletal muscle $[10,14,15]$. cADPR is known to mobilize $\mathrm{Ca}^{2+}$ from the $\mathrm{SR} \mathrm{Ca}^{2+}$ stores through the activation of ryanodine receptors (RyRs) in a wide range of cell types $[16,17]$. Moreover, cADPR has been proposed to serve an additional role in activating the SERCA pump $[18,19]$. However, the exact mechanism by which cADPR regulates SR $\mathrm{Ca}^{2+}$ stores in skeletal muscle cells remains unclear. To explore the mechanism, we analyzed $\mathrm{Ca}^{2+}$ signals as well as the production of $\mathrm{Ca}^{2+}$ mobilizing messengers in the skeletal muscle cells of mice subjected to intensive exercise or in the SR fractions from skeletal muscle cells after $\beta$-AR stimulation.

\section{Materials and Methods}

Animals

CD38 knockout mice (CD38 KO; B6.129P2-Cd38 ${ }^{\text {tm/Lud }}$ ) and CD38 wild type mice (WT) were purchased from The Jackson Laboratory (Bar Harbor, ME). Animals were housed in a $12 \mathrm{hr}$ light-dark schedule with food and water ad libitum. All studies were designed and performed in accordance with the Guide for the Care and Use of Laboratory Animals [20]. The entire project was reviewed and approved by the Institutional Animal Care and Use Committee at Chonbuk National University Medical School (CBU 2016-79).

\section{Cell culture}

C2C12 cells were obtained from ATCC (Manassas, VA). C2C12 cells were maintained in high glucose DMEM, $10 \% \mathrm{FBS}$ at $37^{\circ} \mathrm{C}$ and $5 \% \mathrm{CO}_{2}$. For differentiation, when $\mathrm{C} 2 \mathrm{C} 12$ cells were reached $70 \%$ of confluence, regular media was replaced with high glucose DMEM and 2\% horse serum, and cells were harvested 7 days after initiation of differentiation.

Intensity overload running and submaximal intensity running tests

Exercise test was performed by the method with modifications described previously [21]. Intensity overload running test was performed on the treadmill. The treadmill was set at a speed of $10 \mathrm{~m} / \mathrm{min}$ at a 
Park et al.: cADPR is an Endogenous SERCA Activator

slope of $0^{\circ}$, and speeds were increased at a rate of $1 \mathrm{~m} / \mathrm{min}$ every $2 \mathrm{~min}$. When mouse exhausted, runningtime and distance were measured. Exhaustion was defined by $>10 \mathrm{falls} / \mathrm{min}$ into the motivational grid. Submaximal intensity test was set at a speed of $15 \mathrm{~m} / \mathrm{min}$ at a slope of $0^{\circ}$ for $30 \mathrm{~min}$. The number of falls to the motivational grid was calculated.

\section{Electrical-stimulated muscle contractile force measurement}

Skeletal muscle tension was measured as previously described [22]. Stainless steel hooks were tied with silk sutures to the gastrocnemius muscle tendons. Muscle was transferred to a stimulation chamber (Harvard Apparatus, 73-9916) and mounted between a force transducer (Harvard Apparatus, 76-0098) and an adjustable holder. The chamber temperature $\left(25-37^{\circ} \mathrm{C}\right)$ was maintained with a water-jacketed circulation bath. The muscle was bathed in a high glucose DMEM solution (Thermo scientific); the solution continuously was gassed with $95 \% \mathrm{O}_{2}-5 \% \mathrm{CO}_{2}$. Muscles were stimulated with plate electrodes lysing parallel to the muscle using current pulses ( $5 \mathrm{~Hz}, 55$ Volt). The force signal was sampled with force traducer, and analyzed with Labscribe 2 software (from iworx). Muscle tension was represented and compared as signal intensity/muscle weight.

\section{Isolation of skeletal muscle single fiber}

A single skeletal muscle fiber was obtained from 10 weeks C57BL/6 male mice's gastrocnemius muscle by the method described previously [23]. The isolated muscle samples were placed in $15 \mathrm{ml}$ Falcon tubes containing $8 \mathrm{ml}$ of high glucose Dulbecco's modified Eagle's medium (DMEM) (Invitrogen) and 2\% type I collagenase (Washington) for $90 \mathrm{~min}$ in shaking water bath $(50 \mathrm{rpm})$ at $37^{\circ} \mathrm{C}$. Under $0.6 \mathrm{X}$ stereomicroscopy, healthy singular skeletal muscle fibers were collected with $1 \mathrm{ml}$ pipette tips and transferred to a fresh high glucose DMEM containing 10\% FBS. Isolated muscle fibers were placed in $37^{\circ} \mathrm{C} \mathrm{CO}_{2}$ incubator until using muscle fiber. The muscle was bathed in a high glucose DMEM containing 10\% FBS; the buffer was continuously gassed with $95 \% \mathrm{O}_{2}-5 \% \mathrm{CO}_{2}$.

\section{Preparation of skeletal muscle sarcoplasmic reticulum (SR)}

Skeletal muscle SR was prepared from WT or CD38 KO mice gastrocnemius muscle using a modification of the described previously [24]. 0.5 1 g portion of trimmed gastrocnemius muscle was transferred to 10 $\mathrm{ml}$ round bottom tube to which was added 5 volumes of SR homogenization buffer $\left(10 \mathrm{mM} \mathrm{NaHCO}_{3}, 2 \mathrm{mM}\right.$ sodium azide, $10 \mathrm{mM}$ Tris-HCl, $\mathrm{pH}$ 7.5). The muscle was homogenized on ice using the IKA homogenizer (Ultra Turrex T25, large probe, setting 5) with 3 x 15 s burst and a $30 \mathrm{~s}$ rest between bursts. Homogenate was filtered through two layers of cheesecloth into a $50 \mathrm{ml}$ plastic centrifuge tube and centrifuged at 2 , $000 \mathrm{x} \mathrm{g}$ at $4^{\circ} \mathrm{C}$ for $10 \mathrm{~min}$. The supernatant was collected and retained. To the pellet was added $5 \mathrm{ml}$ of homogenization buffer and re-homogenized with $10 \mathrm{ml}$ glass homogenizer using 20 non-shearing strokes. The suspension was centrifuged at $2,000 \mathrm{xg}, 4^{\circ} \mathrm{C}$ for $10 \mathrm{~min}$ and the supernatant was retained. The pellet was homogenized and centrifuged twice more. The retained supernatant was combined and centrifuged at $10,000 \mathrm{xg}, 4^{\circ} \mathrm{C}$ for $30 \mathrm{~min}$. The pellet was discarded and the supernatant was poured off into $50 \mathrm{ml}$ glass beaker on ice. $\mathrm{KCl}$ ( $4.5 \mathrm{~g} \mathrm{KCl}$ per $100 \mathrm{ml}$ supernatant) was added slowly and stirred with magnetic bar. KCltreated supernatant was centrifuged at $40,000 \mathrm{xg}, 4^{\circ} \mathrm{C}$ for $60 \mathrm{~min}$. The final supernatant was discarded and $0.5 \mathrm{ml}$ of $10 \mathrm{mM}$ Tris-HCl, pH 6 was added to the SR pellet, sufficient to achieve a protein concentration of $2 \mathrm{mg} / \mathrm{ml}$. This was transferred to a $2 \mathrm{ml}$ glass hand homogenizer and suspended thoroughly by application of 20 strokes, avoiding shearing. SR Ca ${ }^{2+}$ release was determined in aliquots of the freshly prepared skeletal muscle SR fraction.

\section{Measurements of intracellular $\mathrm{Ca}^{2+}$ changes}

30-50 skeletal muscle fibers were attached to Matrigel Matrix (BD bioscience) coated dishes. The culture medium was replaced with DMEM containing membrane-permeable $\mathrm{Ca}^{2+}$ indicator Fluo-4 AM or Fluo-5N (Invitrogen). $50 \mathrm{nM} / \mathrm{ml}$ of $\mathrm{Ca}^{2+}$ dyes incubated for $30 \mathrm{~min}$. Intracellular $\mathrm{Ca}^{2+}$ changes, $\left[\mathrm{Ca}^{2+}\right]_{i}$ and SR Ca ${ }^{2+}$ changes, $\left[\mathrm{Ca}^{2+}\right]_{S R}$ were measured with confocal microscopy. (Nikon eclipse $\mathrm{C} 1$ ). Calculations were performed by using an equation given by Tsien et al [25]., i. e., $\left[\mathrm{Ca}^{2+}\right]_{i}=\mathrm{Kd}\left(\mathrm{F}-\mathrm{F}_{\min }\right) /\left(\mathrm{F}_{\max }-\mathrm{F}\right)$, where $\mathrm{Kd}$ is 335 $\mathrm{nM}$ for Fluo 4 and $\mathrm{F}$ is the observed fluorescence levels. Each tracing was calibrated for maximal intensity $\left(\mathrm{F}_{\text {max }}\right)$ by addition of ionomycin $(8 \mu \mathrm{M})$ and for the minimal intensity $\left(\mathrm{F}_{\text {min }}\right)$ by addition of EGTA $50 \mathrm{mM}$ at the end of each measurement. Isoproterenol (ISO) induced changes of $\mathrm{Ca}^{2+}$ amplitude was defined as changes 


\section{Cellular Physiology Cell Physiol Biochem 2018;46:2017-2030 \begin{tabular}{l|l} 
and Biochemistry Published 10.1159/000489441 & $\begin{array}{l}\text { C } 2018 \text { The Author(s). Published by S. Karger AG, Basel } \\
\text { www.karger.com/cpb }\end{array}$ \\
\hline
\end{tabular}}

Park et al.: CADPR is an Endogenous SERCA Activator

of $\mathrm{Ca}^{2+}$ transient peak during electrical stimulation and changes of $\mathrm{Ca}^{2+}$ uptake was defined as time course of $\mathrm{Ca}^{2+}$ transients decay (tau) during $30 \mathrm{sec}$ after electrical stimulation $[5,26]$.

\section{Measurements of sarcoplasmic reticulum fraction $\mathrm{Ca}^{2+}$ changes}

SR fraction $\mathrm{Ca}^{2+}$ measured by a modified method described previously [27]. The kinetics of $\mathrm{Ca}^{2+}$ release was monitored under standard condition at $25^{\circ} \mathrm{C}$ in medium containing $20 \mathrm{mM}$ MOPS-Tris (pH 6.8), $5 \mathrm{mM}$ $\mathrm{MgCl}_{2}, 5 \mathrm{mM}$ sodium oxalate and $20 \mathrm{nM}$ cell impermeable $\mathrm{Ca}^{2+}$ dye, Fluo-2 (TEFLABS). The final concentration of SR vesicle was maintained at $200 \mu \mathrm{g} / \mathrm{ml}$. Fluorescence was recorded in a $1 \mathrm{~cm}$ cuvette with continuous magnetic stirring, using a Photon Technology International (PTI) spectrofluorometer. Simultaneous recordings were obtained at $0.85 \mathrm{~Hz}$, and data was collected and analyzed with the PTI computer interface.

\section{Measurement of intracellular CADPR and NAADP concentration}

Cells were treated with $0.5 \mathrm{~mL}$ of $0.6 \mathrm{M}$ perchloric acid under sonication, and precipitates were removed by centrifugation at 20,000 x g for $10 \mathrm{~min}$. Perchloric acid was removed by mixing the aqueous sample with a solution containing three volumes of $2 \mathrm{M} \mathrm{KHCO}_{3}$. After centrifugation at 15, $000 \mathrm{xg}$ for 10 $\mathrm{min}$, the aqueous layer was collected and neutralized with $20 \mathrm{mM}$ sodium phosphate (pH 8) [ cADPR] and $[\mathrm{NAADP}]_{i}$ were measured using a cyclic enzymatic assay as described previously $[28,29]$.

\section{$\left[{ }^{3} \mathrm{H}\right] \mathrm{cADPR}$ binding assay}

$\left[{ }^{3} \mathrm{H}\right]$ cADPR was synthesized by Aplasia cyclase using $\left[{ }^{3} \mathrm{H}\right]$ NAD (PerkinElmer) and purified by HPLC [30]. To examine the binding of $\left[{ }^{3} \mathrm{H}\right]$ cADPR to SERCA, GST-labeled recombinant $50 \mathrm{ng} / \mathrm{ml}$ SERCA (Abnova) were attached to GST magnetic beads. $10 \mathrm{pM}\left[{ }^{3} \mathrm{H}\right] \mathrm{cADPR}$ binding to recombinant proteins were quantified in the absence and presence of $10 \mu \mathrm{M}$ cADPR.

\section{SERCA activity assay}

SERCA activity measured by the method described previously [31]. SERCA activity was determined from assays in the absence versus presence of $50 \mathrm{nM}$ thapsigargin, a specific inhibitor of SERCA. SERCA protein from exercised muscle sample was immunoprecipitated from $100 \mu \mathrm{g} / \mathrm{ml}$ of skeletal muscle fiber or tissue by using SERCA antibody (Santa Cruz). Recombinant human SERCA2B plasmid was purchased from Addgene (75188). Recombinant SERCA was expressed in HEK293 cell and then purified with immunoaffinity column. Recombinant or immunoprecipitated SERCA proteins were used for measuring activity. Assays were initiated by adding $250 \mu \mathrm{l}$ of reaction buffer containing $25 \mathrm{mM}$ imidazole pH 7, $2 \mathrm{mM} \mathrm{MgATP}, 400 \mu \mathrm{M} \mathrm{CaCl}_{2}$, $50 \mathrm{mM} \mathrm{KCl}$, and $5 \mathrm{mM} \mathrm{MgCl}_{2}$. The reaction proceeded for $20 \mathrm{~min}$ at $22^{\circ} \mathrm{C}$. Blank reaction tubes were contained no calcium and 5 mM EGTA. SERCA activity was assayed over a range of MgATP $(0-250 \mu \mathrm{M})$ and $\mathrm{Ca}^{2+}(0-5$ $\mu \mathrm{M})$ concentrations to determine kinetic constants. SERCA activity was assayed spectrophotometrically by measuring the amount of inorganic phosphate produced using a malachite green/ammonium molybdate dye reagent; this red dye reagent turns green when it forms a complex with inorganic phosphate, and intensity was quantified at $595 \mathrm{~nm}$. The reagent was prepared as previously described [32]. SERCA assays were stopped by removing $50 \mu \mathrm{l}$ aliquots of the assay mix and mixing these into tubes containing $750 \mu \mathrm{l}$ of $\mathrm{ddH}_{2} \mathrm{O}$ and $200 \mu \mathrm{l}$ of the dye reagent. After thorough mixing, color was allowed to develop for $10 \mathrm{~min}$ followed by measurement at $595 \mathrm{~nm}$ using an xMARK microplate reader (Bio-rad). Phosphate quantity was determined from a standard curve prepared with known amounts of $\mathrm{KH}_{2} \mathrm{PO}_{4}$.

\section{Western blot analysis}

Skeletal muscle was homogenized in lysis buffer [20 mM Tris- $\mathrm{HCl}, \mathrm{pH} 7.2,150 \mathrm{mM} \mathrm{NaCl}, 1 \% \mathrm{NP}-40$, $1 \mathrm{mM}$ phenylmethylsulfonyl fluoride, $1 \mathrm{x}$ protease inhibitor cocktail]. The concentration of the extracted proteins in the supernatant was determined by BCA solution (Thermo-fisher Scientific), with BSA as a standard protein. Lysate samples were resolved on 10\% SDS-polyacrylamide gel electrophoresis (SDSPAGE) gel and transferred to polyvinylidine difluoride membrane (GE Healthcare). Antibodies against antiCD38 (Santa Cruz, 1: 2, 500), phospho-CREB1 (S133) (Cusabio, 1: 5, 000), anti-CREB (Cusabio, 1:5, 000), anti-Actin (Santi cruz, 1:5, 000) were used. Horseradish peroxidase-conjugated secondary antibodies (Enzo Life Sciences) were used and visualized with enhanced chemiluminescence. All immunoreactive signals were analyzed by densitometric scanning (Fuji Photo Film Co)

\section{KARGER}




\section{Assay for CD38 promoter activity}

A luciferase activity assay was measured as described previously [33]. pGL4.10-1.9-Luc was constructed with a 1.9-kb genomic DNA encompassing an upstream region of the mouse CD38 gene from the transcription start site $(-1,898 /+3)$ cloned into the KpnI/Xho I sites of the promoterless pGL4.10 basic luciferase reporter plasmid (Promega). pGL4.10-1.9-Luc-0.9 was generated with a 0.9-kb genomic DNA encompassing intron 1 of mouse CD38 from the end of exon $1(+227 /+1,158)$ cloned into the BamH I/ Sal I sites of pGL4.10-1.9-Luc downstream of the luciferase gene. pGL4.10-1.9-Luc-0.9D was generated with the 0.9-kb genomic DNA not containing the putative CRE $(+227 /+1,134)$ cloned into the BamH I/Sal I sites of pGL4.10-1.9-Luc downstream of the luciferase gene. CREB was cloned from skeletal muscle cDNA. pcDNA3.1/V5-His A-CREB (CREB) was constructed into the Hind III/Xba I sites of the pcDNA3.1/V5-His A vector. The luciferase reporter vectors ( $1 \mu \mathrm{g}$ of DNA) were transfected into C2C12 cells using Superfect Transfection Reagent (Qiagen) according to the manufacturer's instructions. The pRL null vector was used as a control. Following transfection, cells were differentiated for 7 days. Subsequently, cells were induced with isoproterenol for $1 \mathrm{~min}$. Luciferase activities were measured using the Dual luciferase assay (Promega) according to the manufacturer's instructions. To monitor transfection efficiency, firefly luciferase activities were normalized with renilla luciferase activities, which were assayed in parallel.

Electrophoretic mobility shift assays (EMSA)

C2C12 cells were transfected with pcDNA3.1/V5-His A-CREB (CREB) or empty pcDNA3.1/V5His A (pcDNA) using Superfect Transfection Reagent (Qiagen). After a 2 days culture, nuclear extracts were prepared from the cells using a NE-PER Nuclear and cytoplasmic Extraction Reagent (Thermo Fisher Scientific). The oligonucleotide harboring the CRE sequences in intron 1 of the mouse CD38 gene (5'-TGATTTCTGAAGTCAAACAGAAA-3') was synthesized, annealed, and labeled with [ $\left.\alpha{ }^{-32} \mathrm{P}\right] \mathrm{dCTP}$. Binding assays with labeled oligonucleotides and $10 \mu \mathrm{g}$ of nuclear extracts were carried out at room temperature for $30 \mathrm{~min}$ in $20 \mu$ l binding buffer solution $(10 \mathrm{mM}$ Tris- $\mathrm{HCl}, \mathrm{pH}$ 7.6, $500 \mathrm{mM} \mathrm{KCl}, 10 \mathrm{mM}$ EDTA, 50\% glycerol, $1 \mu \mathrm{g}$ poly $(\mathrm{dI} \cdot \mathrm{dC}), 1 \mathrm{mM} \mathrm{DTT})$. The reaction mixtures were resolved by $4 \%$ polyacrylamide gel electrophoresis in $0.5 \mathrm{x}$ Tris-borate-EDTA (TBE) buffer solution. The gels were dried and examined by autoradiography. Specificity of the binding was assured by competition with a 30 -fold excess of non-labeled CRE oligonucleotide.

\section{Real-time quantitative PCR}

Total RNA was isolated from skeletal muscle fibers using the Hybrid- $\mathrm{R}^{\mathrm{TM}}$ Kit (GeneAll). cDNAwas synthesized by reverse transcription from 100 ng total RNA using a ImProm-II ${ }^{\mathrm{TM}}$ Reverse Transcription System (Promega). Real-time quantitative PCR was carried out in a 384-well plate using the ABI Prism 7900 HT Sequence Detection System (Thermo Fisher Scientific). Primers for CD38 and GAPDH were 5'-CGCTGCCTCATCTACACTCA-3' (CD 38 forward primer), 5'-TTGCAAGGGTTCTTGGAAAC-3' (CD38 reverse primer), 5'-CGTGGAGTCTACTGGTGTCTT-3' (GAPDH forward primer) and 5'-GTTGGTGGTGCAGGATGCATT-3' (GAPDH reverse primer). PCR conditions consisted of $10 \mathrm{~min}$ at $95^{\circ} \mathrm{C}$, followed by 50 cycles of $15 \sec$ at $95^{\circ} \mathrm{C}$ and $60 \mathrm{sec}$ at $60^{\circ} \mathrm{C}$. Real-time quantitative PCR results were normalized against an internal control GAPDH.

\section{Quantification and statistical analysis}

Data are expressed as means \pm SD. Statistical comparisons were performed with analysis of variance (ANOVA) by using Sigma plot program. Significant differences between groups were determined with the unpaired Student's t test. Statistical significance was set at $p<0.05$.

\section{Results}

CD38 plays a role in muscular contraction in response to $\beta$-AR signaling to sustain a longlasting exercise

Studies using CD38 knockout (KO) mice establish that CD38 is the major enzyme responsible for metabolizing CADPR and is important in regulating a wide range of physiological functions [34-36]. Therefore, we first compared the exercise capabilities of CD38 wild-type (WT) and KO mice through in vivo intensity overload running and submaximal 


\section{Cellular Physiology Cell Physiol Biochem 2018;46:2017-2030 and Biochemistry \begin{tabular}{c|c} 
DOI: 10.1159/000489441 \\
Published online: May 03, 2018 & $\begin{array}{l}\text { O 2018 The Author(s). Published by S. Karger AG, Basel } \\
\text { www.karger.com/cpb }\end{array}$
\end{tabular}

intensity exercise tests. CD38 KO mice failed to adapt to either exercise test (Fig. 1A \& B), indicating that CD38 KO mice have a defect in their capabilities for sustained exercise. Since $\beta$-adrenergic receptor $(\beta$-AR) stimulating hormone concentrations are known to increase markedly during exercise, and contribute to skeletal muscle force generation [37, 38], we postulated that CD38 KO mice may be impaired in skeletal muscle force generation in response to $\beta$-AR signaling. To test this, we examined the effects of $\beta$-AR agonist, isoproterenol (ISO) on the muscle tension test of gastrocnemius muscle (GM) isolated from WT and CD38 KO mice. ISO-induced muscle tension was increased in WT mice, but not CD38 KO mice (Fig. 1C \& D), suggesting that CD38 plays a role in muscular contraction in response to $\beta$-AR signaling.

CADPR is generated by CD38 during exercise and plays a role in $\mathrm{Ca}^{2+}$ uptake in skeletal muscle

CD38 can also produce another $\mathrm{Ca}^{2+}$ signaling messenger, nicotinic acid adenine dinucleotide phosphate (NAADP) [39]. Thus, we asked the question of which

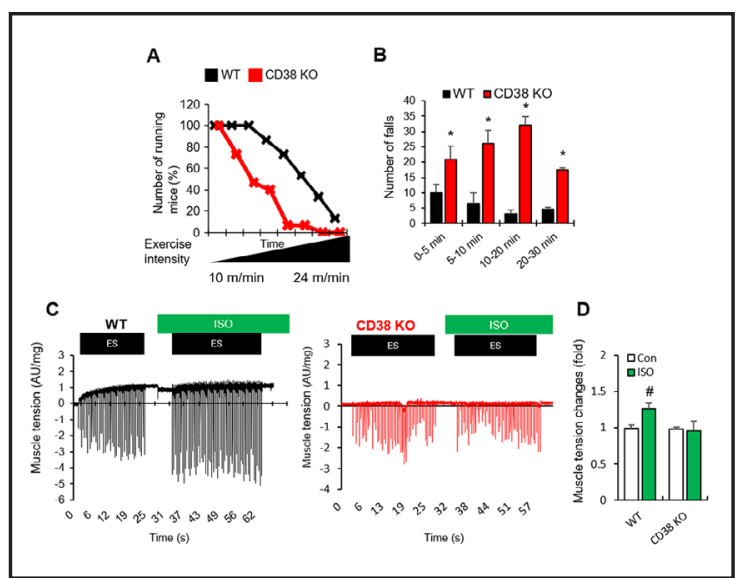

Fig. 1. CD38 KO mice showed lower exercise capabilities, without an increase in ISO-induced muscle contractile force. (A) CD38 KO mice have a defect in response to the intensity overload running test. Exercise intensity was gradually increased from $10 \mathrm{~m} / \mathrm{min}$ to 24 $\mathrm{m} / \mathrm{min}$ in every 2 minutes. (B) Number of falls of WT and CD38 KO mice under 30 min submaximal running test (15 m/min, 0 degree). (C-D) Isoproterenol (ISO; 2 $\mu \mathrm{M})$-mediated contractile force was increased in WT mice, but not CD38 KO mice. Muscle tension was measured in isolated GM tissue during electric stimulation (ES) in the presence or absence of ISO. ${ }^{*}, p<0.05$ versus WT level. \#, $p<0.05$ versus control (Con) level. All data are expressed as the Mean \pm SEM. messenger is defective in the skeletal muscle of CD38 KO mice during exercise or upon $\beta$-AR stimulation. NAADP formation in GM tissue was similar in WT and CD38 KO mice during exercise, while cADPR formation in GM tissue was barely increased in CD38 KO mice, compared to WT mice (Fig. 2A \& B). Consistent with these findings, CD38 has been shown to be responsible for ISO-induced cADPR production, but not NAADP production in cardiomyocytes [11]. We further examined CADPR formation in the muscle fibers from both groups under electrical stimuli (ES) and/ or ISO treatment. ES-induced muscle contraction increased cADPR formation in WT mice muscle fiber, but not CD38 KO mice muscle fiber (Fig. 2C). Although ISO alone increased cADPR formation, under ISO treatment ES synergistically enhanced cADPR formation in WT mice muscle fiber, but not CD38 KO mice muscle fiber (Fig. 2C). These results indicate that CD38in skeletal muscle is responsible for cADPR formation during muscle contraction and CADPR formation is further increased through $\beta$-AR stimulation. During muscle contraction and relaxation, alternating increases and decreases in intracellular $\mathrm{Ca}^{2+}$ results in $\mathrm{Ca}^{2+}$ oscillation [40]. $\beta$-AR signaling increases muscle contraction-induced $\mathrm{Ca}^{2+}$ amplitude and frequency in muscle fibers [5]. Thus, we postulated that CD38-dependent cADPR formation under $\beta$-AR stimulation contributes $\mathrm{Ca}^{2+}$ signals during muscle contraction. To assess this, we examined ES-induced $\mathrm{Ca}^{2+}$ signals in muscle fibers isolated from WT and CD38 KO mice in the presence or absence of ISO. In the presence of ISO, ES-induced $\mathrm{Ca}^{2+}$ amplitudes in WT mice muscle fibers appeared to be relatively higher than those in CD38 KO muscle fibers. Notably, CD38 KO mice showed a delayed $\mathrm{Ca}^{2+}$ transient decay following ES compared to WT mice suggesting that CD38 $\mathrm{KO}$ mice have a defect in their $\mathrm{Ca}^{2+}$ uptake system (Fig. 2D). An antagonistic analog of cADPR, 8-bromo- cADPR (8-Br- cADPR), decreased ISO-induced $\mathrm{Ca}^{2+}$ signals in WT muscle fibers, similar to CD38 KO muscle fibers, and also decreased ISOinduced increment of $\mathrm{Ca}^{2+}$ amplitude (Fig. 2E). Inversely, pretreatment of CD38 KO mice 


\section{Cellular Physiology Cell Physiol Biochem 2018;46:2017-2030 \begin{tabular}{l|l} 
DOI: 10.1159/000489441 & O 2018 The Author(s). Published by S. Karger AG, Basel \\
www.karger.com/cpb
\end{tabular} Park et al.: CADPR is an Endogenous SERCA Activator}

Fig. 2. CD38 knockout muscle cells display impaired ISO-induced $\mathrm{Ca}^{2+}$ signals due to defective cADPR formation. NAADP and cADPR formation and $\mathrm{Ca}^{2+}$ signals were examined in WT and CD38 KO mice during exercise and ES-induced muscle contraction. (A-B) NAADP and cADPR formation in WT and CD38 KO mice GM tissue during treadmill running tests. Exercise intensity was $15 \mathrm{~m} / \mathrm{min}, 0$ degree. (C) Synergistic effect of $2 \mu \mathrm{M}$ ISO on ES-induced muscle contraction-mediated cADPR formation in GM muscle fibers. (D) $2 \mu \mathrm{M}$ ISO treatment enhances ES-induced $\mathrm{Ca}^{2+}$ signals in WT muscle fibers and blunted effect of ISO on ES-induced $\mathrm{Ca}^{2+}$ signals in CD38 KO muscle fibers. (E) 8-Br-cADPR (100 $\mu \mathrm{M})$ suppressed ISOinduced $\mathrm{Ca}^{2+}$ signals in WT muscle fibers. (F) 3-deaza-cADPR (10 pM; Sigma) rescued ISO-induced $\mathrm{Ca}^{2+}$ signals in CD38 KO muscle. Blue and red arrows (D-F) represent changes of $\mathrm{Ca}^{2+}$ amplitude and $\mathrm{Ca}^{2+}$ transient decay, respectively. Peak amplitude were compared before and after treatment with ISO or cADPR analogs. $\mathrm{Ca}^{2+}$ transient decay represents $\mathrm{Ca}^{2+}$ transient decay during $30 \mathrm{sec}$ from end of the ES. (G) 8-bromo-cADPR abolished ISO-induced enhancement of muscle contraction force in WT mice.

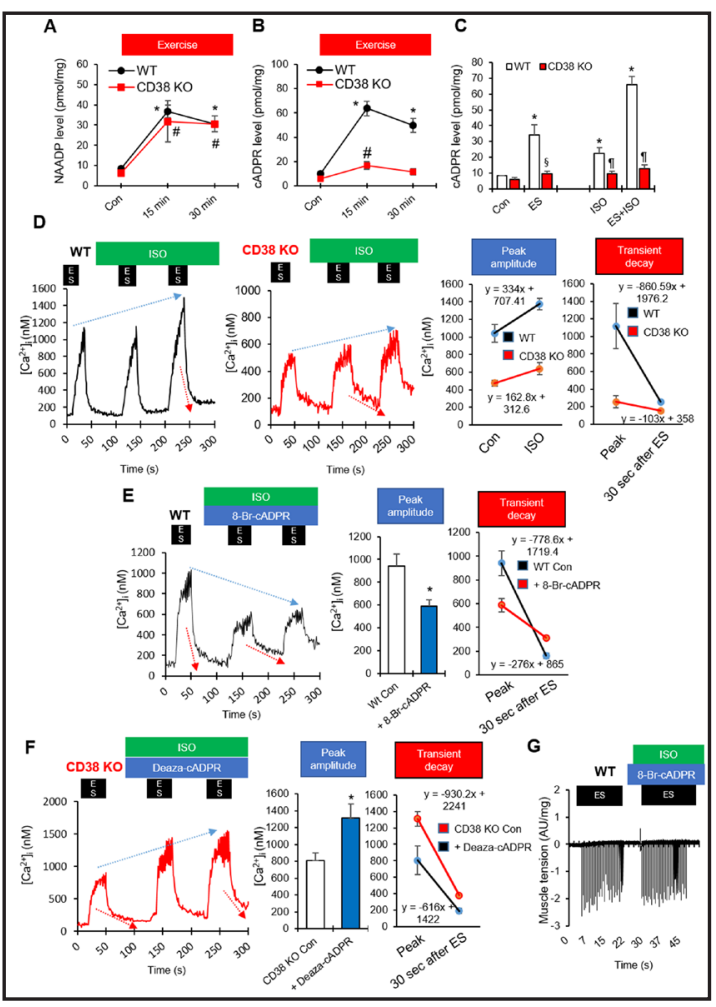
8-bromo-cADPR $(100 \mu \mathrm{M})$ was pretreated for $5 \mathrm{~min}$ before ISO treatment. ", $p<0.05$ versus WT control (Con) level. \#, $p<0.05$ versus CD38 KO Con level. ${ }^{\S}, p<0.05$ versus ES treated level. ${ }^{\top}, p<0.05$ versus ISO treated level. All data are expressed as the Mean \pm SEM.

muscle fibers with a cell-permeable cADPR analog, 3-deaza- cADPR (10 pM), restored the ISO-induced $\mathrm{Ca}^{2+}$ signal to levels observed in WT muscle fibers (Fig. 2F). Furthermore, 8-BrcADPR abolished ISO-induced enhancement of muscle contractile force in WT mice (Fig. 2G). These results indicate that cADPR plays a role in $\mathrm{Ca}^{2+}$ uptake during muscle contraction.

\section{Exercise and ISO upregulate CD38 expression via CREB phosphorylation}

Based on our above findings that cADPR formation by CD38 is responsible for the enhancement of ES-induced $\mathrm{Ca}^{2+}$ signals upon treatment with ISO, we hypothesized that CD38 expression is upregulated by $\beta$-AR signals. To assess this, we examined CD38 expression in GM tissues isolated from WT mice during or after exercise. CD38 expression was increased during exercise, which was sustained until at least for $6 \mathrm{hr}$ of the recovery period (Fig. 3A \& $B$ ). Phosphorylated CREB ( $p$-CREB) levels were also coincidently increased during exercise and recovery (Fig. $3 \mathrm{~A} \& \mathrm{C}$ ). We also examined the effects of ISO on CD38 expression in muscle fibers. ISO increased CD38 mRNA and protein expression as early as $15 \mathrm{sec}$, and this expression was sustained for $120 \mathrm{sec}$, and p-CREB was also increased with a similar time course (Fig. 3D-G). These results suggest that exercise and ISO upregulate CD38 expression via CREB phosphorylation.

\section{CD38 expression is transcriptionally regulated by CREB in response to $\beta$-AR signaling}

Based on our findings of p-CREB-dependent CD38 upregulation by exercise and ISO treatment, we hypothesized that CD38 expression is transcriptionally regulated by CREB. To take advantage of cultured cells for efficient transfection, we tested ISO-induced CD38 expression using skeletal muscle fiber and found that $1-2 \mu \mathrm{M}$ ISO is the optimal concentration for CD38 expression (Fig. 3H). To determine whether the CD38 gene is a transcriptional target for CREB, we searched for the CRE consensus sequences [41], in the CD38 promoter region. A CRE-like motif was observed in the intron 1 region (Fig. 3I). To evaluate the putative CRE sequence, we constructed a luciferase reporter gene plasmid, 
Fig. 3. Effects of exercise and ISO on CD38 expression and CREB phosphorylation in skeletal muscle and the identification of CRE in the mouse CD38 gene. (A-C) GM tissues were extracted from mice after exercise or $6 \mathrm{hr}$ of rest after $30 \mathrm{~min}$ exercise. (D-F) Skeletal muscle fiber were treated with $2 \mu \mathrm{M}$ ISO for the indicated times. (A, D) CD38 expression and CREB phosphorylation. (B, C, E, F) Relative band intensities of CD38 expression and CREB phosphorylation to actin and CREB, respectively. (G) Skeletal muscle cells were treated with ISO $(2 \mu \mathrm{M})$ for the indicated times. CD38 mRNA levels were measured by real-time quantitative PCR. (H) CD38 expression was induced by treatment of $\mathrm{C} 2 \mathrm{C} 12$ myotubes with ISO of indicated concentrations for $1 \mathrm{~min}$. (I) DNA sequence covering exon 1 and part of intron 1 of the CD38 gene. Nucleotide numbering begins at the transcription start site (designated +1 ). The putative CRE motif is boxed. (J) CRE motif in intron 1 of the CD38 gene. Schematic diagram of the CD38 gene (upper). Luciferase reporter plasmids containing the promoter (p1.9-Luc), with (p1.9Luc-0.9) or without CRE (p1.9-Luc-

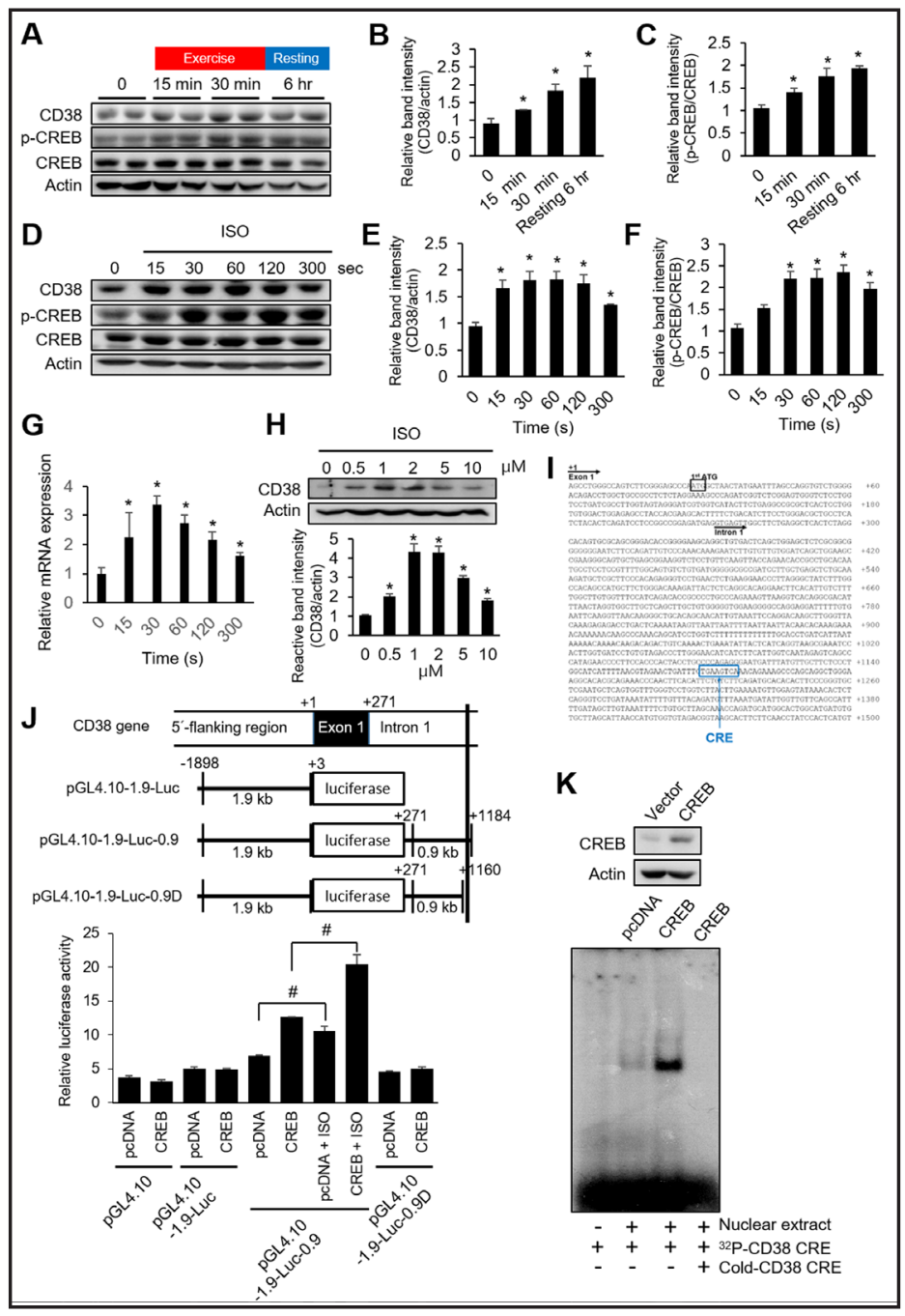
0.9D) were constructed (middle).

After co-transfection with pcDNA or CREB and culture with or without ISO, luciferase activity was assayed (lower). (K) CREB binding to the CRE of the CD38 gene. Skeletal muscle cell (C2C12) were transfected with pcDNA or CREB. CREB expression levels (upper) in nuclear fractions were determined by Western blot. EMSA (lower) was performed with ${ }^{32}$ P-labeled oligonucleotides $(+1162 /+1184$ region of the CD38 gene) with or without unlabeled oligonucleotides. ${ }^{*}, p<0.05$ versus 0 sec level. ${ }^{*}, p<0.05$ versus ISO treated level. All data are expressed as the Mean \pm SEM.

in which a $1.9 \mathrm{~kb}$ upstream region was inserted into the promoter region of the luciferase reporter gene (p1.9-Luc) with or without the putative CRE (Fig. 3J). The transcriptional activity of p1.9-Luc-0.9 was increased 2-fold by the ectopic expression of CREB, and ISO treatment further promoted the transcriptional activity of p1.9-Luc-0.9 (Fig. 3J). In contrast, p1.9-Luc-0.9D showed no or little response to CREB, indicating that the putative CRE may act as a functional transcriptional promoter. Next, we determined whether CREB could actually bind to the putative CRE using electrophoretic mobility shift assays (EMSA). A small fraction of the probe was shifted by nuclear extracts from C2C12 cells, and its shift was amplified by the ectopic expression of CREB, which was abolished by the presence of excessive unlabeled probe (Fig. 3K), indicating that the putative CRE had a specific binding affinity to CREB. Together, these results demonstrated that the CD38 gene is a target for CREB, indicating that $\beta$-AR signaling induces CD38 upregulation. 
Fig. 4. cADPR regulates $\mathrm{SR} \mathrm{Ca}^{2+} \mathrm{lev}$ els during muscle contraction via control of SERCA activity. Skeletal muscle fiber was prepared from of CD38 WT and CD38 KO mice, and the cells were incubated with the $\mathrm{Ca}^{2+}$ dyes Fluo4-AM and Fluo-5N for cytosol and $\mathrm{SR} \mathrm{Ca}^{2+}$, respectively. (A-B) Cytosol (A) and SR (B) $\mathrm{Ca}^{2+}$ signals were measured in the skeletal muscle fiber of WT and CD38 KO mice in the absence or presence of $1 \mu \mathrm{M}$ thapsigargin (Thap). (C) ES-induced SR $\mathrm{Ca}^{2+}$ changes in the skeletal muscle fiber of WT and CD38 KO mice with or without 2 $\mu \mathrm{M}$ ISO treatment. (D) cADPR antagonist, 8-bromo-cADPR $(100 \mu \mathrm{M})$ decreases contraction-induced SR $\mathrm{Ca}^{2+}$ level. Cell permeable cADPR, 3-deaza-cADPR (10 pM) restored contraction-induced SR $\mathrm{Ca}^{2+}$ depletion in CD38 KO mice. (E) Effects of 10 pM cADPR on SR $\mathrm{Ca}^{2+}$ uptake. (F) cADPR increases $\mathrm{SR} \mathrm{Ca}^{2+}$ uptake in a concentration-dependent manner. (G) Inhibition of cADPR-induced SR $\mathrm{Ca}^{2+}$ uptake by $1 \mu \mathrm{M}$ thapsigargin. (H) Dantrolene $(10 \mu \mathrm{M})$ does not block cADPR-induced SR $\mathrm{Ca}^{2+}$ up-

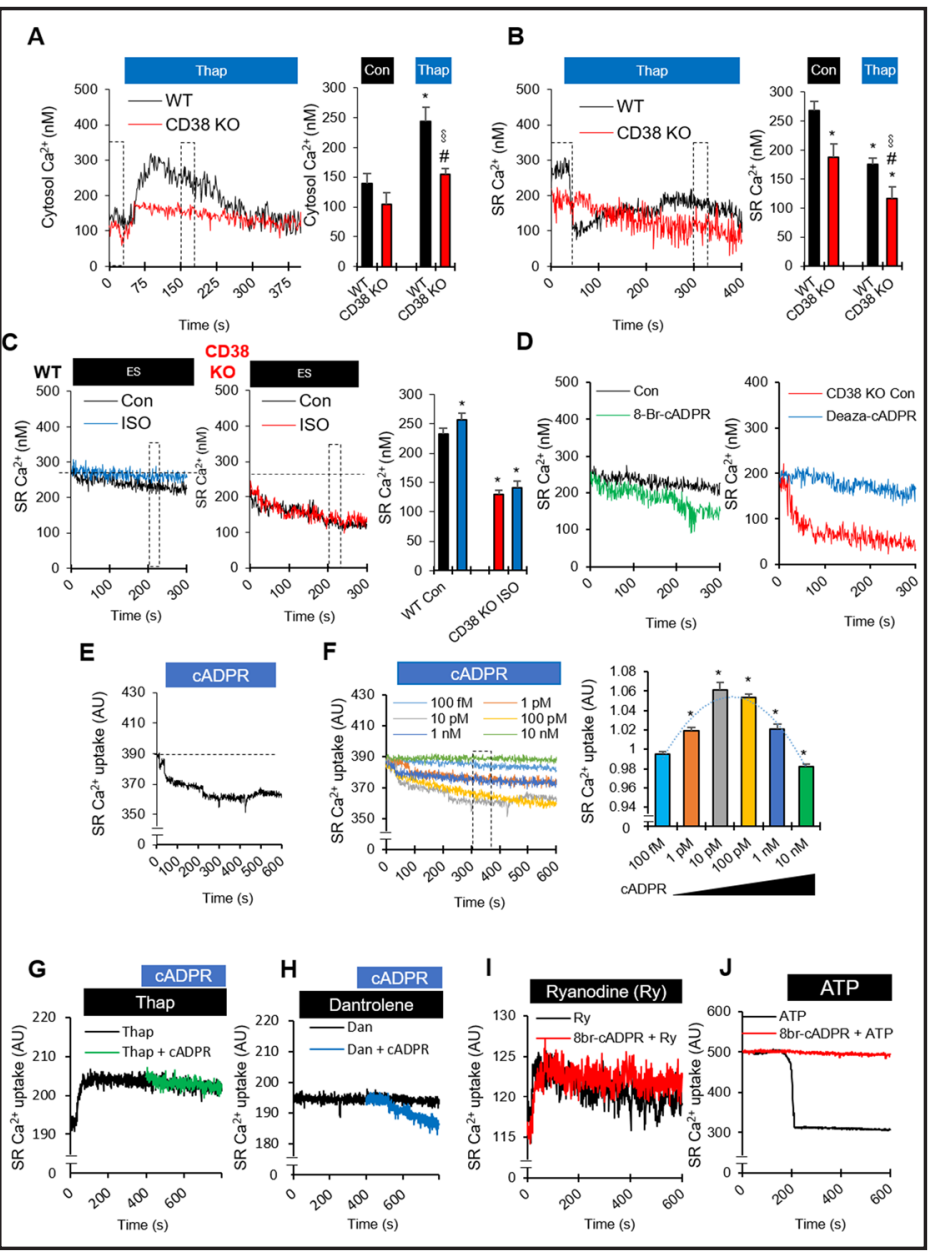
take. (I) 8-Br-cADPR did not inhibit ryanodine (Ry, $50 \mathrm{nM})$-induced SR Ca ${ }^{2+}$ release. (J) ATP $(100 \mu \mathrm{M})$-induced SR $\mathrm{Ca}^{2+}$ uptake was inhibited by 8-br-cADPR $(100 \mu \mathrm{M})$. Ca ${ }^{2+}$ levels (G-J) represent extra-vesicular $\mathrm{Ca}^{2+}$ levels measured by using cell-impermeable $\mathrm{Ca}^{2+}$ dye Fluo-2. Decrement and increment of $\mathrm{Ca}^{2+}$ levels indicate $\mathrm{Ca}^{2+}$ uptake into SR vesicle and $\mathrm{Ca}^{2+}$ release from SR vesicle, respectively. SR vesicle concentration was $200 \mu \mathrm{g} / \mathrm{ml}$. Statistical results of Fig. $4 \mathrm{~F}$ (right panel) represent the values in the dotted rectangle in Fig. 4F (left panel). ${ }^{*}, p<0.05$ versus WT control (Con) level. \#, $p<0.05$ versus CD38 KO Con level. ${ }^{\S}, p<0.05$ versus Thap treated level. All data are expressed as the Mean \pm SEM.

cADPR directly binds to and activates SERCA, thereby enhancing SR $\mathrm{Ca}^{2+}$ uptake

To confirm our findings that cADPR is involved in $\mathrm{Ca}^{2+}$ uptake during muscle relaxation (Fig. 2), we further examined $\mathrm{Ca}^{2+}$ levels in the SR during muscle contraction or ISO treatment by measuring SR $\mathrm{Ca}^{2+}$ with low affinity $\mathrm{Ca}^{2+}$ dye, Fluo-5N [42]. We analyzed the basal levels of SR $\mathrm{Ca}^{2+}$ in WT and CD38 KO mice muscle fibers by using a SERCA inhibitor, thapsigargin (Thap), to deplete SR Ca ${ }^{2+}$. Thap treatment increased cytosolic $\mathrm{Ca}^{2+}$ in both WT and CD38 KO mice muscle fiber, though the levels observed in CD38 KO mice muscle fiber were significantly lower than those in WT mice muscle fiber (Fig. 4A \& C). WT mice muscle fiber showed a large decrease in SR $\mathrm{Ca}^{2+}$ levels with Thap treatment due to higher basal levels, whereas CD38 KO mice muscle fiber showed a small decrease in $\mathrm{SR} \mathrm{Ca}^{2+}$ levels, though this still resulted in lower SR $\mathrm{Ca}^{2+}$ levels than WT mice muscle fiber (Fig. 4B \& C). These data indicate that CD38 KO mice muscle fiber have lower basal SR $\mathrm{Ca}^{2+}$ levels than WT mice muscle fiber. We also measured SR $\mathrm{Ca}^{2+}$ levels during ES-induced muscle fiber contraction with or without ISO treatment. ISO treatment prevented SR $\mathrm{Ca}^{2+}$ levels from decreasing during muscle fiber contraction in WT mice, but not in CD38 KO mice (Fig. 4C). Moreover, 8-Br- cADPR treatment decreased SR Ca ${ }^{2+}$ 
Fig. 5. cADPR directly binds to and activates SERCA.(A) Concentration-dependent effects of cADPR on recombinant SERCA activity. (B) Immunoprecipitated SERCA activities of SR from skeletal muscle of WT and CD38 KO mice before and after exercise. (C) Binding of cADPR to recombinant SERCA. *,

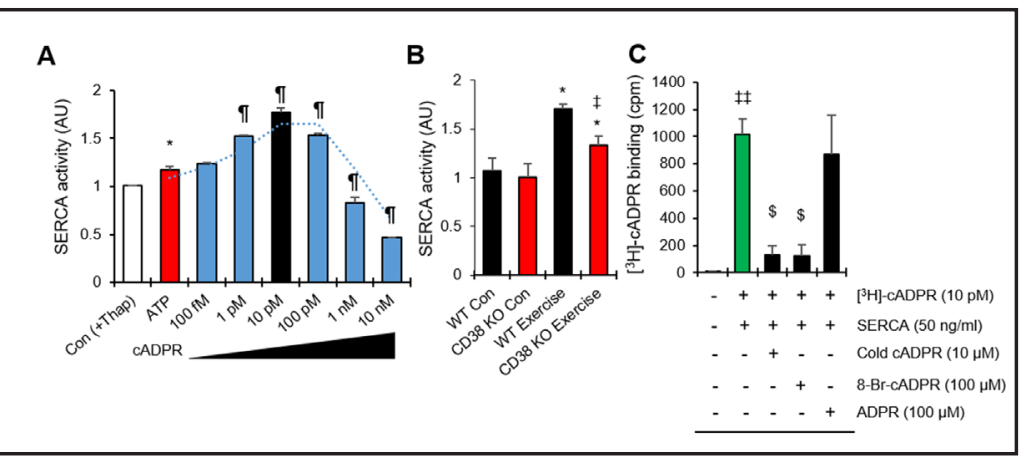
$p<0.05$ versus WT control

(Con) level. ${ }^{\pi,}, p<0.05$ versus ATP treated level. ${ }^{\ddagger}, p<0.05$ versus WT exercise level. ${ }^{\ddagger}, p<0.05$ versus without SERCA protein level. ${ }^{\$}, p<0.05$ versus $\left[{ }^{3} \mathrm{H}\right]$-cADPR treatment with SERCA protein level. All data are expressed as the Mean \pm SEM.

levels during muscle fiber contraction in WT mice, and 3-deaza- cADPR prevented SR $\mathrm{Ca}^{2+}$ depletion during muscle fiber contraction in CD38 KO mice (Fig. 4D). These data suggest that ISO-induced cADPR formation is responsible for maintaining $\mathrm{SR} \mathrm{Ca}^{2+}$ levels through SR $\mathrm{Ca}^{2+}$ uptake during muscle contraction. Since SR $\mathrm{Ca}^{2+}$ uptake is regulated by SERCA [43], we examined the effects of cADPR on SR $\mathrm{Ca}^{2+}$ levels. We isolated SR fractions from GM and analyzed $\mathrm{Ca}^{2+}$ levels outside of the SR by using a cell-impermeable $\mathrm{Ca}^{2+}$ dye, Fluo-2. cADPR treatment increased SR $\mathrm{Ca}^{2+}$ uptake in SR fractions in a time and concentration-dependent manner (Fig. 4E \& 4F). To clarify the target ofc ADPR, we examined the effects of a SERCA inhibitor, Thap, or a RyR1 inhibitor, dantrolene, on cADPR-induced SR $\mathrm{Ca}^{2+}$ changes. Thap completely inhibited cADPR-induced SR $\mathrm{Ca}^{2+}$ changes (Fig. 4G), while dantrolene did not block cADPR-induced SR Ca ${ }^{2+}$ changes (Fig. $4 \mathrm{H}$ ). To further examine the effect of cADPR on $\mathrm{SR} \mathrm{Ca}^{2+}$ release, we performed experiments using ryanodine and 8-Br- cADPR to examine cADPR function. Our data showed that 8-Br- cADPR did not inhibit ryanodine-induced SR $\mathrm{Ca}^{2+}$ release, whereas 8-Br- cADPR inhibited ATP-induced SR $\mathrm{Ca}^{2+}$ uptake (Fig. 4I \& J). These results indicate that cADPR is not involved in $\mathrm{SR} \mathrm{Ca}^{2+}$ releasing event, but induces $\mathrm{SR} \mathrm{Ca}^{2+}$ uptake by acting on SERCA.

We next examined the effects of cADPR on SERCA activity by using recombinant SERCA protein, and found that CADPR increased SERCA activity in a concentration-dependent manner, with an optimum concentration of $10 \mathrm{pM}$ (Fig. 5A), which is consistent with data regarding optimum concentrations for $\mathrm{SR} \mathrm{Ca}^{2+}$ uptake (Fig. 4F). Because cADPR activates SERCA, we also measured SERCA activity in GM from WT and CD38 KO mice before and after exercise. SERCA activity from the GM of CD38 KO mice did not show much of an increase after exercise when compared to WT muscle (Fig. 5B). To determine whether cADPR activates SERCA in a direct or indirect fashion, we performed a binding study using $\left[{ }^{3} \mathrm{H}\right]$ cADPR against recombinant purified SERCA $\left[{ }^{3} \mathrm{H}\right]$. CADPR bound to SERCA, which was inhibited by the addition of excessive unlabeled cADPR or 8-Br- cADPR. Other CD38 product, ADP-ribose (ADPR), had no effect on $\left[{ }^{3} \mathrm{H}\right]$ cADPR binding to SERCA (Fig. 5C). These results indicate that cADPR directly binds to and activates SERCA, thereby enhancing SR $\mathrm{Ca}^{2+}$ uptake.

\section{Discussion}

In the present study we demonstrate that exercise or $\beta$-AR stimulation increases skeletal muscle contractile force through CD38 expression via CREB-mediated transcription and CD38-dependent cADPR formation. Moreover, cADPR activates the SERCA pump and enhances SR $\mathrm{Ca}^{2+}$ uptake in skeletal muscle cells, which is essential in maintaining muscle contractile force. Thus, CD38 plays a crucial role in muscle contraction during exercise and cADPR is an endogenous activator of SERCA. 


\section{Cellular Physiology Cell Physiol Biochem 2018;46:2017-2030 \\ \begin{tabular}{l|l} 
DOI: 10.1159/000489441 & O 2018 The Author(s). Published by S. Karger AG, Basel \\
www.karger.com/cpb
\end{tabular} \\ Park et al.: CADPR is an Endogenous SERCA Activator}

In skeletal muscle, the activation of intramuscular $\mathrm{Ca}^{2+}$ release by the ryanodine receptors (RyR1) occurs through a physical interaction with the voltage gated dihydropyridine receptor. After contraction, the SERCA performs the critical function of promoting muscle relaxation by sequestering $\mathrm{Ca}^{2+}$ from the cytoplasm at the expense of ATP hydrolysis [2]. Although exercise is known to promote skeletal muscle contractility $[5,6]$, there are few studies showing the effect of intensive exercise on the handling of $\mathrm{Ca}^{2+}$ by skeletal muscle. The activation of $\beta$-AR not only increases contractility, but also enhances relaxation (lusitropy), and the fast SR $\mathrm{Ca}^{2+}$ uptake contributes to the SR $\mathrm{Ca}^{2+}$ content, enabling high $\mathrm{Ca}^{2+}$ signals and contractile force. Our findings indicate that cADPR increases force production during muscle contraction by increasing SERCA activity, suggesting that $\mathrm{SR} \mathrm{Ca}^{2+}$ loading via $\mathrm{Ca}^{2+}$ uptake is as important as $\mathrm{Ca}^{2+}$ release for muscle contraction.

CD38 KO mice showed defects in the formation of cADPR in skeletal muscle during exercise, whereas their capacity in producing NAADP during exercise remained untouched (Fig. 2A \& B), indicating that CD38 mediates the production of cADPR, but not NAADP, in skeletal muscle under $\beta$-AR stimulation. Although CD38 is known to be a responsible enzyme for both cADPR and NAADP synthesis in vitro and in some cells [12,34], it is not likely the case in skeletal muscle cell. These findings are consistent with our previous research that CD38 mediates only cADPR formation in cardiomyocytes in response to ISO treatment [11]. Moreover, NAADP was prerequisite for cADPR formation in ISO- treated cardiomyocytes. This suggests that NAADP and cADPR are sequentially produced by a nonCD38 NAADP synthesizing enzyme (NSE) and CD38, respectively, upon $\beta$-AR stimulation, and skeletal muscle cells likely express an as-yet-unidentified NSE that may be regulated in a cAMP-dependent manner. This notion has been proved by our previous findings that the production of NAADP was induced in a cAMP-dependent manner in cardiomyocytes and pancreatic $\beta$ cells $[44,45]$. Thus, we presume that the stimulation of $\beta$-AR initially results in the production of NAADP for the release of $\mathrm{Ca}^{2+}$ from $\mathrm{Ca}^{2+}$ stores, most likely the SR. Our finding that exercise or ISO induces the transcription of CD38 via CREB indicates that $\beta$-AR regulates $\mathrm{Ca}^{2+}$ signals through CD38 upregulation via cAMP-dependent transcription. Of note, the effect of CREB activation on CD38 expression by ISO treatment was very quick. A previous report demonstrated a similarly quick CREB phosphorylation, peak of which was within 1 minute in neuroblastoma cells upon bradykinin treatment [46]. Given that $\beta$-adrenergic signaling in skeletal muscle is a typical flight-to-fight response, it may not be surprising to see the quick response of CREB activation by ISO treatment. These findings suggest that $\mathrm{Ca}^{2+}$ signals are operated through the formation of $\mathrm{Ca}^{2+}$ messengers and the rapid expression of $\mathrm{CD} 38$ under $\beta$-AR signaling during exercise.

cADPR was first shown to release $\mathrm{Ca}^{2+}$ from intracellular stores by the activation of ryanodine-sensitive $\mathrm{Ca}^{2+}$-release channels in sea urchin eggs [47]. Mészáros et al, reported that cADPR increases the open probability of cardiac ryanodinesensitive $\mathrm{Ca}^{2+}$-release channels in planar lipid bilayers [48]. Takasawa et al, demonstrated that cADPR induces insulin secretion in digitonin-permeabilized islets, supporting the notion that cADPR acts on the cardiac isoform of RyR [17]. On the other hand, a controversial report by [49] demonstrated that cADPR tends to decrease open probability in the presence of $100 \mu \mathrm{M}$ ATP, which is a subphysiological cytosolic concentration in cardiac cells. This finding argues against the idea that cADPR can exert an effect on channel gating in in cardiac muscle cells. Our findings showing that cADPR activates SERCA activity, thereby enhancing SR $\mathrm{Ca}^{2+}$ uptake [18], is contrary to previous findings that suggest cADPR causes $\mathrm{SR} \mathrm{Ca}^{2+}$ release [17]. We demonstrated the activation of SERCA, as well as $\mathrm{SR} \mathrm{Ca}^{2+}$ uptake, in skeletal muscle cells without the cardiac isoform of RyR. Notably, cADPR shows a bell-shaped concentrationresponse curve in the activation of SERCA activity and the enhancement of SR $\mathrm{Ca}^{2+}$ uptake, with an optimum concentration at $10 \mathrm{pM}$ (Fig. 4E \& F). This concentration is 10, 000-fold lower than that required for $\mathrm{SR} \mathrm{Ca}^{2+}$ release from various cell types, ranging from sea urchin eggs to pancreatic $\beta$ cells [17], suggesting that the action of cADPR on SERCA is highly sensitive and physiologically relevant. 
In summary, based on in vivo and in vitro studies, our observations provide strong support for the role of cADPR as an endogenous SERCA activator towards increasing SR $\mathrm{Ca}^{2+}$ uptake and contractile force in skeletal muscle in response to $\beta$-AR agonist. Our findings provide insight into the physiologically adaptive mechanism by which CD38 is expressed during muscle contraction through the rapid transcriptional regulation by CREB. Thus, the paradoxical role of cADPR for $\mathrm{Ca}^{2+}$-mobilization and $\mathrm{Ca}^{2+}$-uptake activity should be further clarified in the other physiological system.

\section{Acknowledgements}

The authors thank Mr. Chansu Park for critical reading of the manuscript. This work was supported by a Korean National Research Foundation Grant 2012R1A3A2026453 (to UHK).

\section{Disclosure Statement}

No conflict of interests exists.

\section{References}

1 Heilbrunn LV, Wiercinski FJ: The action of various cations on muscle protoplasm. J Cell Comp Physiol 1947;29:15-32.

- Bers DM: Cardiac excitation-contraction coupling. Nature 2002;415:198-205.

-3 Ringer S, Buxton DW: Concerning the Action of Calcium, Potassium, and Sodium Salts upon the Eel's Heart and upon the Skeletal Muscles of the Frog. J Physiol 1887:8:15-19.

4 Zouhal H, Jacob C, Delamarche P, Gratas-Delamarche A: Catecholamines and the effects of exercise, training and gender. Sports Med 2008;38:401-423.

-5 Ha TN, Posterino GS, Fryer MW: Effects of terbutaline on force and intracellular calcium in slow-twitch skeletal muscle fibres of the rat. Br J Pharmacol 1999;126:1717-1724.

6 Cairns SP, Dulhunty AF: The effects of $\beta$-adrenoceptor activation on contraction in isolated fast-and slowtwitch skeletal muscle fibres of the rat. Br J Pharmacol 1993:110:1133-1141.

7 Rah S-Y, Lee Y-H, Kim U-H: NAADP-mediated $\mathrm{Ca}^{2+}$ signaling promotes autophagy and protects against LPSinduced liver injury. FASEB J 2017;31:3126-3137.

-8 Park D-R, Park K-H, Kim B-J, Yoon C-S, Kim U-H: Exercise ameliorates insulin resistance via $\mathrm{Ca}^{2+}$ signals distinct from those of insulin for glut4 translocation in skeletal muscles. Diabetes 2015;64:1224-1234.

-9 Park K-H, Kim B-J, Kang J, Nam T-S, Lim JM, Kim HT, Park JK, Kim YG, Chae S-W, Kim U-H: Ca ${ }^{2+}$ signaling tools acquired from prostasomes are required for progesterone-induced sperm motility. Sci Signal 2011;4:ra31.

10 Lewis AM, Aley PK, Roomi A, Thomas JM, Masgrau R, Garnham C, Shipman K, Paramore C, Bloor-Young D, Sanders LE, Terrar DA, Galione A, Churchill GC: ß-adrenergic receptor signaling increases NAADP and cADPR levels in the heart. Biochem Biophys Res Commun 2012;427:326-329.

11 Gul R, Park D-R, Shawl AI, Im S-Y, Nam T-S, Lee S-H, Ko J-K, Jang KY, Kim D, Kim U-H: Nicotinic acid adenine dinucleotide phosphate (NAADP) and cyclic ADP-ribose ( cADPR) mediate $\mathrm{Ca}^{2+}$ signaling in cardiac hypertrophy induced by $\beta$-adrenergic stimulation. PloS one 2016;11:e0149125.

12 Lee HC: Cyclic ADP-ribose and nicotinic acid adenine dinucleotide phosphate (NAADP) as messengers for calcium mobilization. J Biol Chem 2012;287:31633-31640.

13 Kim U-H: Multiple enzymatic activities of CD38 for $\mathrm{Ca}^{2+}$ signaling messengers. Messenger 2014;3:6-14.

14 Park D-R, Shawl AI, Ha T-G, Park K-H, Kim S-Y, Kim U-H: Arginine thiazolidine carboxylate stimulates insulin secretion through production of $\mathrm{Ca}^{2+}$-mobilizing second messengers NAADP and cADPR in pancreatic islets. PloS one 2015;10:e0134962.

15 Soares S, Thompson M, White T, Isbell A, Yamasaki M, Prakash Y, Lund FE, Galione A, Chini EN: NAADP as a second messenger: neither CD38 nor base-exchange reaction are necessary for in vivo generation of NAADP in myometrial cells. Am J Physiol Cell Physiol 2007;292:C227-C239. 


\section{Cellular Physiology Cell Physiol Biochem 2018;46:2017-2030 \begin{tabular}{l|l} 
DOI: 10.1159/000489441 & $\begin{array}{l}\text { O 2018 The Author(s). Published by S. Karger AG, Basel } \\
\text { www.karger.com/cpb }\end{array}$ \\
\hline
\end{tabular}}

-16 Partida-Sánchez S, Cockayne DA, Monard S, Jacobson EL, Oppenheimer N, Garvy B, Kusser K, Goodrich S, Howard M, Harmsen A, Randall TD, Lund FE: Cyclic ADP-ribose production by CD38 regulates intracellular calcium release, extracellular calcium influx and chemotaxis in neutrophils and is required for bacterial clearance in vivo. Nat Med 2001;7:1209-1216.

17 Takasawa S, Nata K, Yonekura H, Okamoto H: Cyclic ADP-ribose in insulin secretion from pancreatic beta cells. Science 1993;259:370-374.

-18 Yamasaki-Mann M, Demuro A, Parker I: cADPR stimulates serca activity in xenopus oocytes. Cell Calcium 2009;45:293-299.

19 Macgregor AT, Rakovic S, Galione A, Terrar DA: Dual effects of cyclic ADP-ribose on sarcoplasmic reticulum $\mathrm{Ca}^{2+}$ release and storage in cardiac myocytes isolated from guinea-pig and rat ventricle. Cell Calcium 2007;41:537-546.

20 Council NR et al. (2010) Guide for the care and use of laboratory animals. (National Academies Press).

-21 Wilson JM, Loenneke JP, Jo E, Wilson GJ, Zourdos MC, Kim JS: The effects of endurance, strength, and power training on muscle fiber type shifting. J Strength Cond Res 2012;26:1724-1729.

-22 Katz A, Hernández A, Caballero DM, Briceno JF, Amezquita LV, Kosterina N, Bruton JD, Westerblad H: Effects of $\mathrm{N}$-acetylcysteine on isolated mouse skeletal muscle: contractile properties, temperature dependence, and metabolism. Pflugers Arch 2014;466:577-585.

23 Rosenblatt JD, Lunt AI, Parry DJ, Partridge TA: Culturing satellite cells from living single muscle fiber explants. In vitro Cell Dev Biol Anim 1995;31:773-779.

24 Hemmings SJ: New methods for the isolation of skeletal muscle sarcolemma and sarcoplasmic reticulum allowing a comparison between the mammalian and amphibian $\beta 2$-adrenergic receptors and calcium pumps. Cell Biochem Funct 2001;19:133-141.

25 Tsien, RY, Pozzan T, Rink TJ: T-cell mitogens cause early changes in cytoplasmic free $\mathrm{Ca}^{2+}$ and membrane potential in lymphocytes. Nature 1982;295:68-71.

-26 Ottenheijm CA, Fong C, Vangheluwe P, Wuytack F, Babu GJ, Periasamy M, Witt CC, Labeit S, Granzier H: Sarcoplasmic reticulum calcium uptake and speed of relaxation are depressed in nebulin-free skeletal muscle. FASEB J 2008:22:2912-2919.

27 Berman MC: Characterisation of thapsigargin-releasable $\mathrm{Ca}^{2+}$ from the $\mathrm{Ca}^{2+}$-atpase of sarcoplasmic reticulum at limiting $\left[\mathrm{Ca}^{2+}\right]$. Biochim Biophys Acta 2000;1509:42-54.

-28 Graeff R, Lee HC: A novel cycling assay for cellular cADP-ribose with nanomolar sensitivity. Biochem J 2002;361:379-384.

29 Graeff R, Lee HC: A novel cycling assay for nicotinic acid-adenine dinucleotide phosphate with nanomolar sensitivity. Biochem J 2002;367:163-168.

-30 Gasser A, Guse AH: Determination of intracellular concentrations of the trpm2 agonist ADP-ribose by reversed-phase hplc. J Chromatogr B Analyt Technol Biomed Life Sci 2005;821:181-187.

-31 Ramnanan C, McMullen D, Bielecki A, Storey K: Regulation of sarcoendoplasmic reticulum $\mathrm{Ca}^{2+}$-atpase (serca) in turtle muscle and liver during acute exposure to anoxia. J Exp Biol 2010;213:17-25.

-32 Feng J, Chen Y, Pu J, Yang X, Zhang C, Zhu S, Zhao Y, Yuan Y, Yuan H, Liao F: An improved malachite green assay of phosphate: mechanism and application. Anal Biochem 2011;409:144-149.

-33 Song E-K, Lee Y-R, Kim Y-R, Yeom J-H, Yoo C-H, Kim H-K, Park H-M, Kang H-S, Kim J-S, Kim, U-H, Han M-K: NAADP mediates insulin-stimulated glucose uptake and insulin sensitization by ppar $\gamma$ in adipocytes. Cell Rep 2012;2:1607-1619.

-34 Rah S-Y, Mushtaq M, Nam T-S, Kim SH, Kim U-H: Generation of cyclic ADP-ribose and nicotinic acid adenine dinucleotide phosphate by CD38 for $\mathrm{Ca}^{2+}$ signaling in interleukin-8-treated lymphokine-activated killer cells. J Biol Chem 2010;285:21877-21887.

35 Jin D, Liu HX, Hirai H, Torashima T, Nagai T, Lopatina O, Shnayder NA, Yamada K, Noda M, Seike T, Fujita K, Takasawa S, Yokoyama S, Koizumi K, Shiraishi Y, Tanaka S, Hashii M, Yoshihara T, Higashida K, Islam MS, Yamada N, Hayashi K, Noguchi N, Kato I, Okamoto H, Matsushima A, Salmina A, Munesue T, Shimizu N, Mochida S, Asano M, Higashida H: CD38 is critical for social behaviour by regulating oxytocin secretion. Nature 2007;446:41-45.

-36 Deshpande DA, White TA, Guedes AG, Milla C, Walseth TF, Lund FE, Kannan MS: Altered airway responsiveness in cd38-deficient mice. Am J Respir Cell Mol Biol 2005;32:149-156. 


\section{Cellular Physiology Cell Physiol Biochem 2018;46:2017-2030 \begin{tabular}{l|l} 
DOI: 10.1159/000489441 & and Biochemistry \\
Published 2018 The Author(s). Published by S. Karger AG, Basel \\
www.karger.com/cpb
\end{tabular} \\ Park et al.: CADPR is an Endogenous SERCA Activator}

37 Deuster PA, Chrousos GP, Luger A, DeBolt JE, Bernier LL, Trostmann UH, Kyle SB, Montgomery LC, Loriaux DL: Hormonal and metabolic responses of untrained, moderately trained, and highly trained men to three exercise intensities. Metabolism 1989;38:141-148.

-38 Richter EA, Ruderman NB, Galbo H: Alpha and beta adrenergic effects on metabolism in contracting, perfused muscle. Acta Physiol Scand 1982;116:215-222.

-39 Lee HC: Cyclic ADP-ribose and NAADP: fraternal twin messengers for calcium signaling. Sci China Life Sci 2011;54:699-711.

-40 Vergara J, DiFranco M, Compagnon D, Suarez-Isla BA: Imaging of calcium transients in skeletal muscle fibers. Biophys j 1991;59:12-24.

41 Carlezon WA, Duman RS, Nestler EJ: The many faces of creb. Trends Neurosci 2005;28:436-445.

42 Picht E, DeSantiago J, Blatter LA, Bers DM: Cardiac alternans do not rely on diastolic sarcoplasmic reticulum calcium content fluctuations. Circ Res 2006;99:740-748.

43 Lytton J, Westlin M, Hanley MR: Thapsigargin inhibits the sarcoplasmic or endoplasmic reticulum CaATPase family of calcium pumps. J Biol Chem 1991;266:17067-17071.

44 Kim B-J, Park K-H, Yim C-Y, Takasawa S, Okamoto H, Im M-J, Kim U-H: Generation of nicotinic acid adenine dinucleotide phosphate and cyclic ADP-ribose by glucagon-like peptide- 1 evokes $\mathrm{Ca}^{2+}$ signal that is essential for insulin secretion in mouse pancreatic islets. Diabetes 2008;57:868-878.

45 Xie GH, Rah SY, Kim SJ, Nam TS, Ha KC, Chae SW, Im MJ, Kim UH: ADP-ribosyl cyclase couples to cyclic AMP signaling in the cardiomyocytes. Biochem Biophys Res Commun 2005;330:1290-1298.

-46 Rosethorne EM, Nahorski SR, Challiss RA: Regulation of cyclic AMP response-element binding-protein (CREB) by Gq/11-protein-coupled receptors in human SH-SY5Y neuroblastoma cells. Biochem Pharmacol. 2008:75:942-955.

47 Galione A, Lee HC, Busa WB: $\mathrm{Ca}^{2+}$-induced $\mathrm{Ca}^{2+}$ release in sea urchin egg homogenates: modulation by cyclic ADP-ribose. Science 1991;253:1143-1146.

48 Mészáros LG, Bak J, Chu A: Cyclic ADP-ribose as an endogenous regulator of the non-skeletal type ryanodine' receptor $\mathrm{Ca}^{2+}$ channel. Nature 1993;364:76-79.

49 Sitsapesan R, McGarry SJ, Williams AJ: Cyclic ADP-ribose competes with atp for the adenine nucleotide binding site on the cardiac ryanodine receptor $\mathrm{Ca}^{2+}$-release channel. Circ Res 1994; 75:596-600. 